\title{
PERANCANGAN SISTEM INFORMASI AKADEMIK BERBASIS WEBSITE PADA SEKOLAH TINGGI ANALIS BAKTI ASIH BANDUNG
}

\author{
Tubagus Riko Rivanthio, S.Kom., M.Kom. \\ Dosen Prodi Manajemen Informatika \\ Politeknik LP3I Bandung \\ Email: riko_rivanthio@yahoo.com
}

\begin{abstract}
Abstrak: Sistem Informasi Akademik merupakan suatu sistem yang dapat mengelola data kegiatan sivitas akademik suatu perguruan tinggi. Pengelolaan data tersebut akan menghasilkan informasi yang berguna baik untuk mahasiswa, dosen maupun lembaga itu sendiri. Namun tidak semua perguruan tinggi sudah menerapkan sistem informasi akademik. Sekolah Tinggi Analis Bakti Asih Bandung merupakan perguruan tinggi yang belum memiliki sistem informasi akademik dalam mengelola kegiatan perkuliahannya. Dalam mengelola kegiatan akademiknya, Sekolah Tinggi Analis Bakti Asih Bandung masih menggunakan aplikasi office yang bebasis offline. Sehingga untuk mengatasi masalah tersebut, maka peranan sistem informasi akademik sangat dibutuhkan oleh Sekolah Tinggi Analis Bakti Asih Bandung. Dengan adanya sistem informasi akademik diharapkan bagian akademik Sekolah Tinggi Analis Bakti Bandung dapat meningkatkan pelayanan terhadap mahasiswa, dosen maupun orang tua mahasiswa.
\end{abstract}

Kata Kunci: Sistem Informasi, Akademik, Pengelolaan Data

\section{Pendahuluan}

\subsection{Latar Belakang Masalah}

Sistem Informasi Akademik merupakan suatu sistem yang dapat mengelola data kegiatan sivitas akademik suatu perguruan tinggi. Pengelolaan data tersebut akan menghasilkan informasi yang berguna baik untuk mahasiswa, dosen maupun lembaga itu sendiri. Contohnya adalah pengelolaan data nilai mahasiswa, data jadwal kuliah, pembagian dosen wali, merekap kehadiran mahasiswa, menghitung Indeks Prestasi Mahasiswa, dan lain sebagainya yang berhubungan kegiatan perkuliahan.

Sistem Informasi Akademik bukan hanya bermanfaat untuk mahasiswa dan dosen saja, namun bermanfaat juga bagi orang tua mahasiswa agar dapat mengetahui perkembangan belajar mahasiswa. Hal ini disebabkan karena saat ini banyak lembaga perguruan tinggi yang sudah menerapkan sistem informasi akademiknya berbasis online, sehingga orang tua mahasiswa dengan mudah mengakses sistem informasi akademik yang dibuat oleh perguruan tinggi. Selain untuk keperluan mahasiswa, dosen, dan orang tua, namun sistem informasi akdemik juga bermanfaat bagi lembaga itu sendiri. Dengan adanya sistem informasi akademik maka lembaga dengan mudah mengevaluasi hasil penerapan kurikulum yang diberikan kepada mahasiswa dalam menghasilkan lulusan yang berkompeten sesuai dengan harapan dunia kerja.

Namun tidak semua perguruan tinggi sudah menerapkan sistem informasi akademik. Sekolah Tinggi Analis Bakti Asih Bandung merupakan perguruan tinggi yang belum memiliki sistem informasi akademik dalam mengelola kegiatan perkuliahannya. Dalam 
mengelola kegiatan akademiknya, Sekolah Tinggi Analis Bakti Asih Bandung masih menggunakan aplikasi office yang bebasis offline, sehingga bagian akademi sering mengalami kesulitan dalam mengelola kegiatan akademiknya. Begitu pula dengan mahasiswa yang kesulitan dalam melihat nilai dan Indek Prestasi yang telah mereka raih.

Sehingga untuk mengatasi masalah tersebut, maka peranan sistem informasi akademik sangat dibutuhkan oleh Sekolah Tinggi Analis Bakti Asih Bandung. Dengan adanya sistem informasi akademik diharapkan bagian akademik Sekolah Tinggi Analis Bakti Bandung dapat meningkatkan pelayanan tehadap mahasiswa, dosen maupun orang tua mahasiswa.

\subsection{Rumusan Masalah}

Dalam latar belakang telah diuraikan bahwa Sekolah Tinggi Analis Bakti Asih Bandung belum memiliki Sistem Informasi Akademik sehingga kesulitan dan keterlambatan dalam melakukan pelayanan terhadap mahasiswa, dosen maupun orang tua mahasiswa. Maka dari itu dibutuhkan perancangan untuk pembuatan sistem informasi akademik. Beberapa masalah yang akan muncul dalam perancangan adalah :

a. Bagaimana sistem akademik yang berjalan pada Sekolah Tinggi Analis Bakti Asih Bandung?

b. Bagaimana sistem informasi akademik yang diusulkan untuk Sekolah Tinggi Analis Bakti Asih Bandung?

\section{Landasan Teori}

\subsection{Sistem Informasi Akademik}

\section{a. Sistem}

Sistem adalah suatu rangkaian yang terdiri dari dua atau lebih komponen yang saling berhubungan dan saling berinteraksi satu sama lain untuk mencapai tujuan dimana sistem biasanya terbagi dalam sub system yang lebih kecil yang mendukung system yang lebih besar. Romney dan Steinbart (2015:3)

Sedangkan menurut Mulyadi(2016:5) sistem adalah suatu jaringan prosedur yang dibuat menurut pola yang terpadu untuk melaksanakan kegiatan pokok perusahaan.

b. Informasi

Menurut Gellinas and Dull (2012:12) informasi merupakan data yang disajikan dalam suatu bentuk yang berguna terhadap aktifitas pengambilan keputusan.

Ada beberapa karakteristik informasi yang berkualitas, yaitu:

1) Effectiveness : berkaitan dengan informasi yang relevan dan berkaitan dengan proses bisnis yang di sampaikan dengan tepat waktu, benar, konsistem dan dapat digunakan.

2) Efficiency informasi yang berkaitan melalui penyediaan informasi secara optimal terhadap penggunaan sumber daya.

3) Confidentiality : karakteristik informasi yang berkaitan dengan keakuratan dan kelengkapan informasi serta validitasnya sesuai dengan nilai-nilai bisnis dan harapan. 
4) Integrity : karakteristik informasi yang berkaitan dengan perlindungan terhadap informasi yang sensitif dari pengungkapan yang tidak sah.

5) Availability: suatu karakteristik informasi yang berkaitan dengan informasi yang tersedia pada saat diperlukan oleh proses bisnis baik sekarang, maupun di masa mendatang, hal ini juga menyangkut perlindungan sumber daya yang diperlukan dan kemampuan yang terkait.

6) Compliance : yaitu karakteristik informasi yang berkaitan dengan mematuhi peraturan dan perjanjian kontrak dimana proses bisnis merupakan subjek nya berupa kriteria bisnis secara internal maupun eksternal.

7) Reliability : karakteristik informasi yang berkaitan dengan penyediaan informasi yang tepat bagi manajemen untuk mengoperasikan entitas dan menjalankan tanggung jawab serta tata kelola pemerintahan.

c. Sistem Informasi

Menurut Gelinas dan Dull (2012:12) Sistem Informasi adalah sistem yang dibuat secara umum berdasarkan seperangkat komputer dan komponen manual yang dapat dikumpulkan, disimpan dan diolah untuk menyediakan output kepada user.

Berikut ciri-ciri sistem informasi menurut Ardana dan Lukman :

1) Satu Kesatuan: Satu-Kesatuan organisasi,

2) Bagian-Bagian: ada manajemen, karyawan, pemangku kepentingan (stakeholder) lainnya, gedung kantor, sub-sistem komputer (perangkat keras, perangkat lunak, perangkat jaringan, sumber dayamanusia, basis data dan informasi).

3) Terjalin erat: tercermin dalm bentuk hubungan, interaksi, prosedur kerja antar manajemen,

4) Mencapai tujuan: menghasilkan informasi yang berkualitas bagi manajemen dan pemangku kepentingan lainnya.

\section{d. Sistem Informasi Akademik}

Menurut Amarusu (2013), pengertian sistem informasi akademik adalah : Sistem secara khusus dirancang untuk memenuhi kebutuhan perguruan tinggi yang menginginkan layanan pendidikan yang terkomputerisasi untuk meningkatkan kinerja, kualitas pelayanan, daya saing dan kualitas SDM yang dihasilkannya.Secara singkat sistem informasi akademik dapat diartikan aplikasi untuk membantu memudahkan pengelolaan data-data dan informasi yang berkaitan dengan instansi pendidikan.

\subsection{UML}

\section{a. Definisi UML}

Unified Modeling Language (UML) adalah salah satu standar bahasa yang banyak digunakan di dunia industri untuk mendefinisikan requirement, membuat analisis dan desain, serta menggambarkan arsitektur dalam pemrograman berorientasi objek. UML merupakan bahasa visual untuk pemodelan dan komunikasi mengenai sebuah sistem dengan menggunakan diagram dan teks-teks pendukung. 
UML muncul karena adanya kebutuhan pemodelan visual untuk menspesifikasikan, menggambarkan, membangun, dan dokumentasi dari sistem perangkat lunak. UML hanya berfungsi untuk melakukan pemodelan. Jadi penggunaan UML tidak terbatas pada metodologi tertentu, meskipun pada kenyataannya UML paling banyak digunakan pada metodologi berorientasi objek (Rosa A.S dan M. Shalahudin, 2014:133).

b. Use Case Diagram

Rosa dan M. Shalahudin (2014:155), use case atau diagram use case merupakan pemodelan untuk kelakuan (behavior) sistem informasi yang akan dibuat. Use case mendeskripsikan sebuah interaksi antara satu atau lebih aktor dengan sistem informasi yang akan dibuat. Secara kasar, use case digunakan untuk mengetahui fungsi apa saja yang ada di dalam sebuah sistem informasi dan siapa saja yang berhak menggunakan fungsi-fungsi itu.

Tabel 1. Simbol Use Case Diagram

\begin{tabular}{|c|c|c|}
\hline Nama sintaks & Penjelasan & Sintaks \\
\hline Aktor & $\begin{array}{l}\text { - Orang atau sistem } \\
\text { - Digarnbarkan sebagai stick figure atau jika } \\
\text { melibatkan bukan manusia digambarkan } \\
\text { dengan c<aktoras } \\
\text { - Diberi label peranan } \\
\text { - Dapat diasosiasikan dengan aktor lainnya } \\
\text { menggunakan spesialisasi atau spesialigasi } \\
\text { superkelas. }\end{array}$ & \\
\hline Use Cast & $\begin{array}{l}\text { - Merepresentseikan bagian fungionalitse } \\
\text { sistem } \\
\text { - Dapat dihubungkan secara extend dengan } \\
\text { use case laimrya } \\
\text { - Dapat dihubungkan secara include dengan } \\
\text { use case lairuny } \\
\text { - Diternpatkan dalam batasan sistem } \\
\text { - Diber label mengunakan deskripei kata } \\
\text { kerja-non frase }\end{array}$ & \\
\hline Batsean subject & $\begin{array}{l}\text { - Merepresentasikan skop subjek misalnya } \\
\text { sebuah sistern atau bagian proses bisnis. }\end{array}$ & \\
\hline $\begin{array}{l}\text { Association } \\
\text { Relationeluig: }\end{array}$ & $\begin{array}{l}\text { - Tautan aktor dengan use case yang } \\
\text { beninteraksi }\end{array}$ & \\
\hline $\begin{array}{l}\text { Include } \\
\text { Relationship: }\end{array}$ & $\begin{array}{l}\text { - Merepesentasikan inklusi fungionalitss } \\
\text { suatu use case dengan yang lainnya. }\end{array}$ & exinchadess. \\
\hline $\begin{array}{l}\text { Extend } \\
\text { Relationship: }\end{array}$ & $\begin{array}{l}\text { - Merepresentasikan perluasan use case he } \\
\text { include tingkah laku pilikan }\end{array}$ & <emeends> \\
\hline $\begin{array}{l}\text { Generalisen: } \\
\text { Relationship: }\end{array}$ & $\begin{array}{l}\text { - Merepresentasikan spesialisasi use case ke } \\
\text { suatu generahisusi }\end{array}$ & \\
\hline
\end{tabular}




\section{c. Actvity Diagram}

Rosa dan M. Shalahudin (2014:161), diagram aktivitas atau activity diagram menggambarkan workflow (aliran kerja) atau aktivitas dari sebuah sebuah sistem atau proses bisnis atau menu yang ada pada perangkat lunak. Yang perlu di perhatikan disini adalah bahwa diagram aktivitas menggambarkan aktivitas sistem bukan apa yang dilakukan aktor, jadi aktivitas yang dapat dilakukan oleh sistem.

Tabel 2. Simbol Activity Diagram

\begin{tabular}{|c|c|}
\hline Simbol & Deskripsi \\
\hline status awal & $\begin{array}{l}\text { status awal aktivitas sistem, } \\
\text { sebuah diagram aktivitas } \\
\text { memiliki sebuah status awal }\end{array}$ \\
\hline aktivitas & $\begin{array}{l}\text { aktivitas yang dilakukan sistem, } \\
\text { aktivitas biasanya diawali dengan } \\
\text { kata kerja }\end{array}$ \\
\hline percabangan / decision & $\begin{array}{l}\text { asosiasi percabangan dimana jika } \\
\text { ada pilihan aktivitas lebih dari } \\
\text { satu }\end{array}$ \\
\hline penggabungan / join & $\begin{array}{l}\text { asosiasi penggabungan dimana } \\
\text { lebih dari satu aktivitas } \\
\text { digabungkan menjadi satu }\end{array}$ \\
\hline status akhir & $\begin{array}{l}\text { status akhir yang dilakukan } \\
\text { sistem, sebuah diagram aktivitas } \\
\text { memiliki sebuah status akhir }\end{array}$ \\
\hline nama swimlane & $\begin{array}{l}\text { memisahkan organisasi bisnis } \\
\text { yang bertanggung jawab } \\
\text { terhadap aktivitas yang terjadi }\end{array}$ \\
\hline fork, & $\begin{array}{l}\text { digunakan utk menunjukkan } \\
\text { kegiatan yg dilakukan secara } \\
\text { paralel }\end{array}$ \\
\hline join, & $\begin{array}{l}\text { digunakan utk menunjukkan } \\
\text { kegiatan yg digabungkan }\end{array}$ \\
\hline
\end{tabular}




\section{d. Class Diagram}

Rosa dan M. Shalahudin (2014:141), diagram kelas atau class diagram menggambarkan struktur sistem dari segi pendefinisian kelas-kelas yang akan dibuat untuk membangun sistem. Kelas memiliki apa yang disebut atribut dan method atau operasi. Berikut penjelasan atribut dan method :

1) Atribut merupakan variable-variabel yang dimiliki oleh suatu kelas.

2) Operasi atau method adalah fungsi-fungsi yang dimiliki oleh suatu kelas.

Tabel 3. Simbol Class Diagram

\begin{tabular}{|c|c|c|l|}
\hline NO & GAMBAR & NAMA & \multicolumn{1}{|c|}{ KETERANGAN } \\
\hline 1 & - Generalizotion & $\begin{array}{l}\text { Hubungan dimana objek anak } \\
\text { (descendent) berbagi perilaku dan } \\
\text { struktur data dari objek yang ada di } \\
\text { atasnya objek induk (ancestor). }\end{array}$ \\
\hline 3 & & $\begin{array}{c}\text { Nary } \\
\text { Association }\end{array}$ & $\begin{array}{l}\text { Upaya untuk menghindari asosiasi } \\
\text { dengan lebih dari 2 objek. }\end{array}$ \\
\hline 4 & \multirow{2}{*}{ Class } & $\begin{array}{l}\text { Himpunan dari objek-objek yang berbagi } \\
\text { atribut serta operasi yang sama. }\end{array}$ \\
\hline 5 & $4 \ldots$ & Collaboration & $\begin{array}{l}\text { Deskripsi dari urutan aksi-aksi yang } \\
\text { ditampilkan sistem yang menghasilkan } \\
\text { suatu hasil yang terukur bagi suatu aktor }\end{array}$ \\
\hline 7 & Realization & $\begin{array}{l}\text { Operasi yang benar-benar dilakukan oleh } \\
\text { suatu objek. }\end{array}$ \\
\hline & Dependency & $\begin{array}{l}\text { Hubungan dimana perubahan yang } \\
\text { terjadi pada suatu elemen mandiri } \\
\text { (independent)akan mempegaruhi elemen } \\
\text { yang bergantung padanya elemen yang } \\
\text { tidak mandiri }\end{array}$ \\
\hline
\end{tabular}

e. Sequence Diagram

Rosa dan M. Shalahudin (2014:165), diagram sekuen menggambarkan kelakuan objek pada use case dengan mendeskripsikan waktu hidup objek dengan massage yang dikirimkan dan diterima antar objek. Oleh karena itu untuk menggambarkan diagram sekuen maka harus diketahui objek-objek yang terlibat dalam sebuah use case beserta metode-metode yang dimiliki kelas yang diinstansiasi menjadi objek itu. Membuat diagram sekuen juga dibutuhkan untuk melihat skenario yang ada pada use case. Banyaknya diagram sekuen yang harus digambar adalah minimal sebanyak pendefinisian 
use case yang memiliki proses sendiri atau yang penting semua use case yang telah didefinisikan interaksi jalannya pesan sudah dicakup dalam diagram sekuen sehingga semakin banyak use case yang didefinisikan maka diagram sekuen yang harus dibuat juga semakin banyak.

Tabel 4. Simbol Sequence Diagram

\begin{tabular}{|c|c|c|}
\hline$O^{\text {aktor }}$ atau & nama_aktor & $\begin{array}{l}\text { - orang, proses, atau sistem lain yang berinteraksi dengan sistem } \\
\text { informasi dan mendapat mantaat dari system. } \\
\text { - Berpartisipasi secara berurutan dengan mengirimkan } \\
\text { dan / atau menerima pésan. } \\
\text { - Diternpatkan di bagian atas diagran. }\end{array}$ \\
\hline $\begin{array}{l}\text { objek } \\
\qquad \text { obj }\end{array}$ & kelas & $\begin{array}{l}\text { Sebuah objek: } \\
\text { Berpartisipasi secara berurutan dengan mengirimkan } \\
\text { dan / atau menerima pesan. } \\
\text { - Ditempatkan di bagian atas diagram. }\end{array}$ \\
\hline Garis hid & objek & $\begin{array}{l}\text { - Menandakan kehidupan obyek selama } \\
\text { urutan. } \\
\text { - diakhiri tanda X pada titik di mana } \\
\text { kelas tidak lagi berinteraksi. }\end{array}$ \\
\hline $\begin{array}{l}\text { Objek se } \\
\text { berintera }\end{array}$ & ang aktif & $\begin{array}{l}\text { Fokus kontrol: } \\
\text { - Adalah persegi panjang yang sempit panjang } \\
\text { ditempatkan di atas sebuah garis hidup. } \\
\text { - Menandakan ketika suatu objek mengirim atau } \\
\text { menerima pesan. }\end{array}$ \\
\hline $\begin{array}{l}\text { pesan } \\
\text { pe }\end{array}$ & $\operatorname{an} 0$ & $\begin{array}{l}\text { objek mengirim satu pesan ke } \\
\text { objek lainya }\end{array}$ \\
\hline$<<$ crea & & $\begin{array}{l}\text { menyatakan suatu objek membuat objek } \\
\text { yang lain, arah panah mengarah pada } \\
\text { objek yang dibuat }\end{array}$ \\
\hline 1 :masul & & $\begin{array}{l}\text { menyatakan bahwa suatu objek } \\
\text { mengirimkan masukan ke objek lainnya } \\
\text { arah panah mengarah pada objek yang } \\
\text { dikirimi }\end{array}$ \\
\hline - 1:kelua & $-\rightarrow$ & $\begin{array}{l}\text { objek/metode menghasilkan suatu } \\
\text { kembalian ke objek tertentu, arah panah } \\
\text { mengarah pada objek yang menerima } \\
\text { kembalian }\end{array}$ \\
\hline & oy0 & $\begin{array}{l}\text { menyatakan suatu objek mengakhiri hidup } \\
\text { objek yang lain, arah panah mengarah pada } \\
\text { objek yang diakhiri, sebaiknya jika ada create } \\
\text { maka ada destroy }\end{array}$ \\
\hline
\end{tabular}

\section{Pembahasan}

\subsection{Sistem Akademik yang berjalan}

Sistem informasi yang sedang berjalan pada Sekolah Tinggi Analis Bakti Asih Bandung belum sepenuhnya menggunakan komputerisasi dalam mengolah dan menampilkan data. Pada saat ini pengolahannya belum menggunakan sistem informasi, masih menggunakan 
aplikasi excel untuk mengolah datanya. Berikut ini adalah sistem yang sedang berjalan pada Sekolah Tinggi Analis Bakti Asih Bandung.

\section{Sistem KRS}

a. Sistem pengisian krs masih menggunakan manual, yaitu mengisi lembar Formulir Rencana Studi (FRS), setelah

b. Setelah FRS diisi kemudian diperiksa oleh Dosen wali untuk kesesuaian persyaratan pengambilan mata kuliah yang telah diberlakukan, dan dosen wali menandatangani FRS yang telah diisi oleh mahasiswa

c. Kemudian FRS yang telah ditandatangani oleh dosen wali tersebut diberikan ke BAAK untuk diinput ke file Excel

d. Setelah itu BAAK membuat dan mencetak KRS untuk mahasiswa.

Adapun proses sistem KRS bisa dilihat digambar 1.

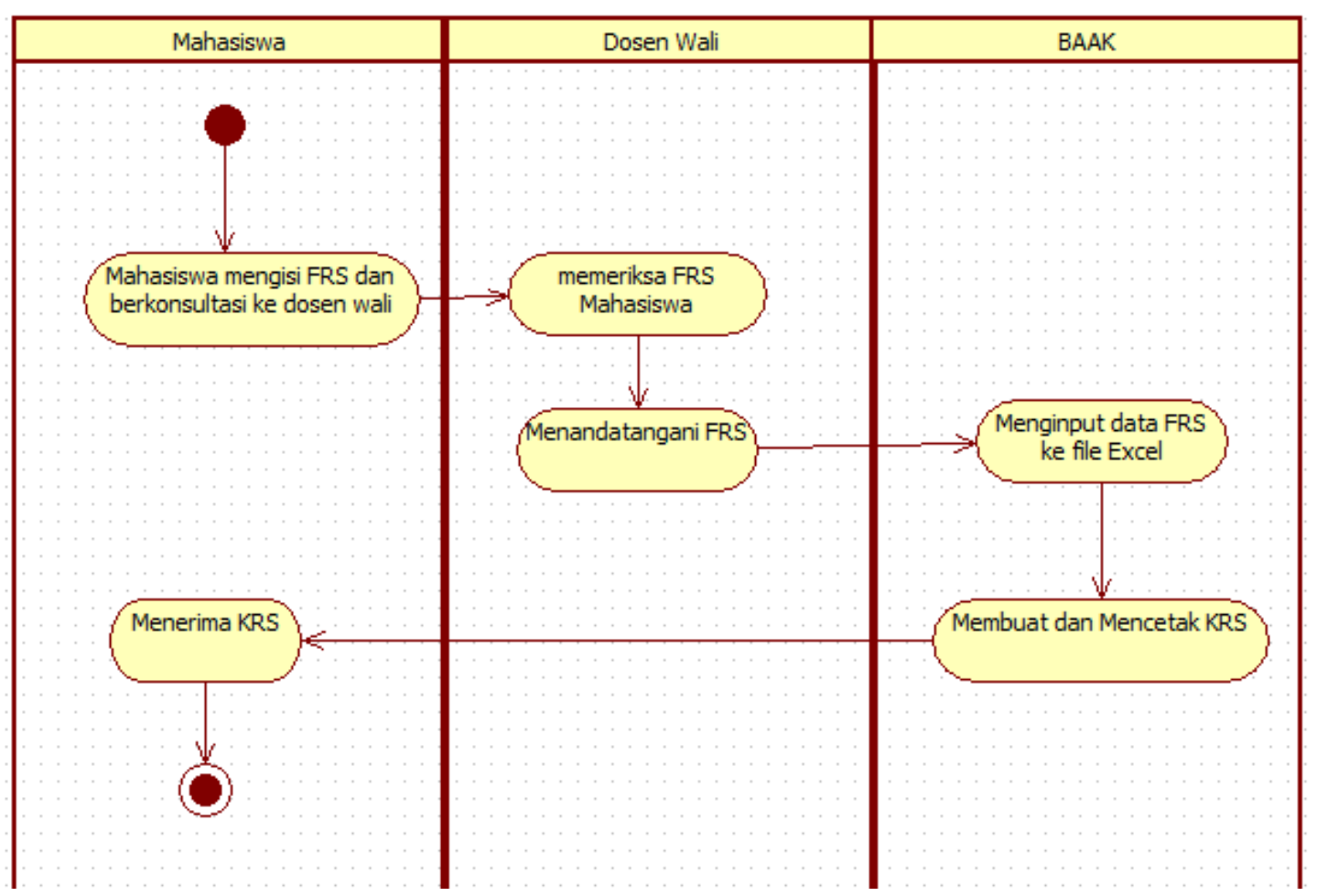

Gambar 1. Diagram Aktivitas KRS

2. Sistem Pembuatan Jadwal Perkuliahan

a. BAAK merekap data KRS mahasiswa dan mengkonfirmasi jadwal kesiapan dosen untuk mengajar mata kuliah.

b. Setelah mendapatkan data jumlah kelas dan konfirmasi jadwal kesiapan mengajar dosen, BAAK membuat jadwal perkuliahan.

c. Kemudian BAAK mencetak jadwal yang sudah dibuat dan mensosialisasikan jadwal tersebut ke dosen dan mahasiswa. 
d. Selain mencetak jadwal, BAAK juga mencetak Berita Acara dan Lembar Kehadiran Mahasiswa.

Adapun proses sistem Pembuatan Jadwal Perkuliahan bisa dilihat digambar 2.

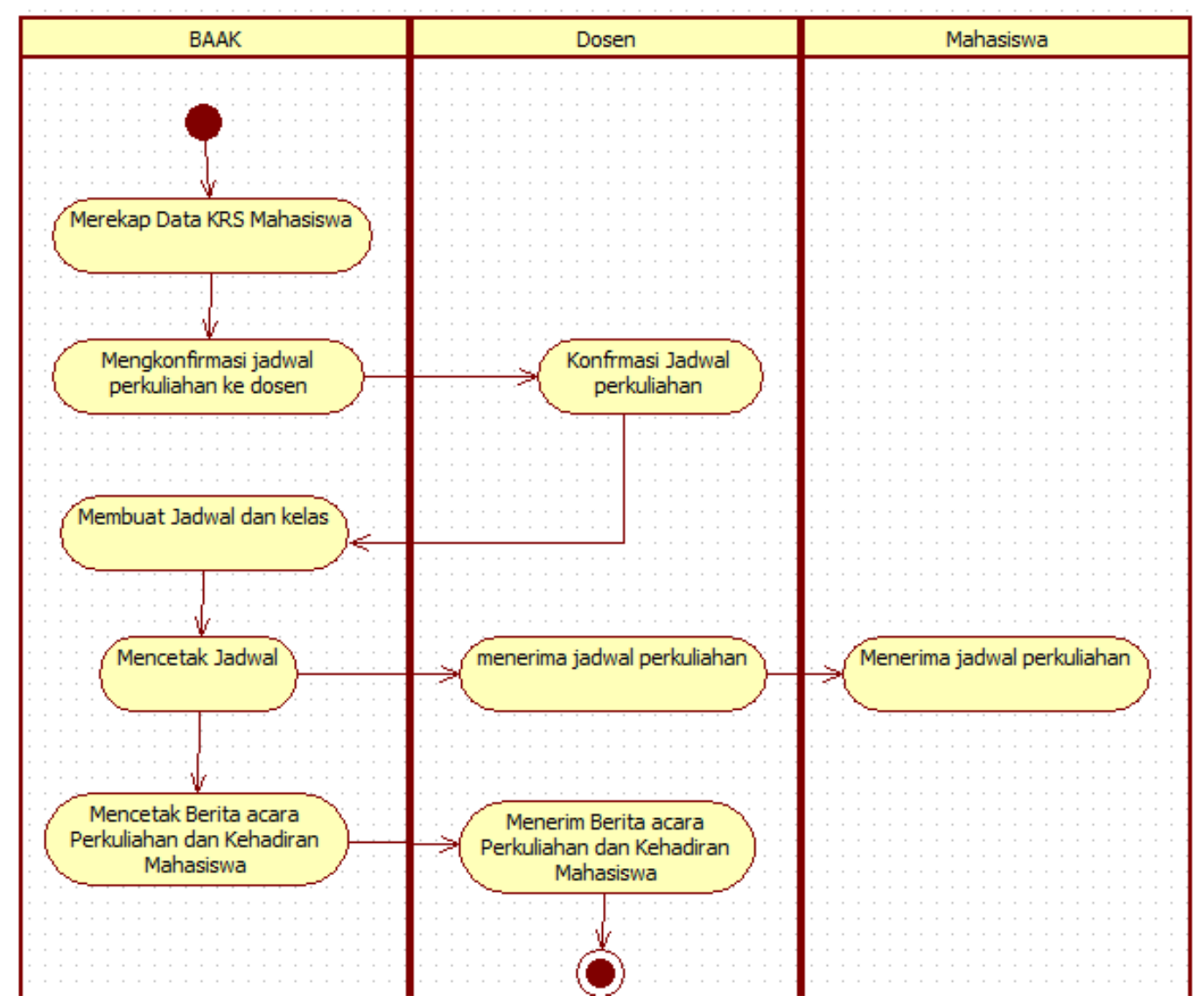

Gambar 2. Diagram Aktivitas Pembuatan Jadwal

3. Sistem Nilai Mahasiswa

a. Dosen merekap nilai mahasiswa

b. Kemudian dosen memberikan rekapan nilai tersebut ke BAAK

c. Rekapan nilai tersebut akan diinput oleh BAAK ke file Excel

d. Kemudian BAAK mencetak nilai mahasiswa setiap mata kuliah.

Adapun proses sistem nilai mahasiswa bisa dilihat digambar 3 . 


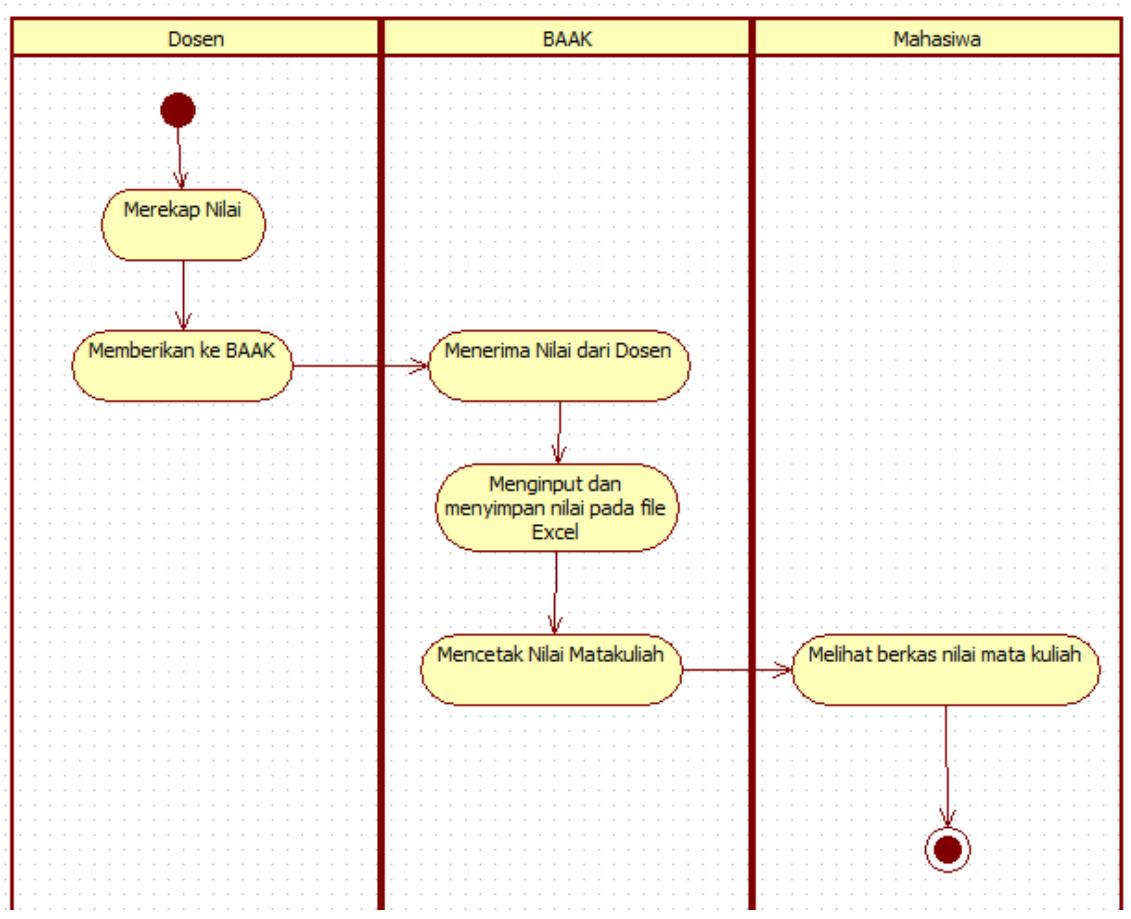

Gambar 3. Diagram Aktivitas Input Nilai Mahasiswa

\subsection{Sistem Akademik yang diusulkan}

\section{Diagram Use Case}

Diagram use case digunakan untuk menggambarkan interaksi antara sistem informasi akademik yang dibuat dengan aktor-aktor yang terlibat. Adapun diagram use case yang diusulkan adalah sebagai berikut dapat dilihat pada gambar 4 .

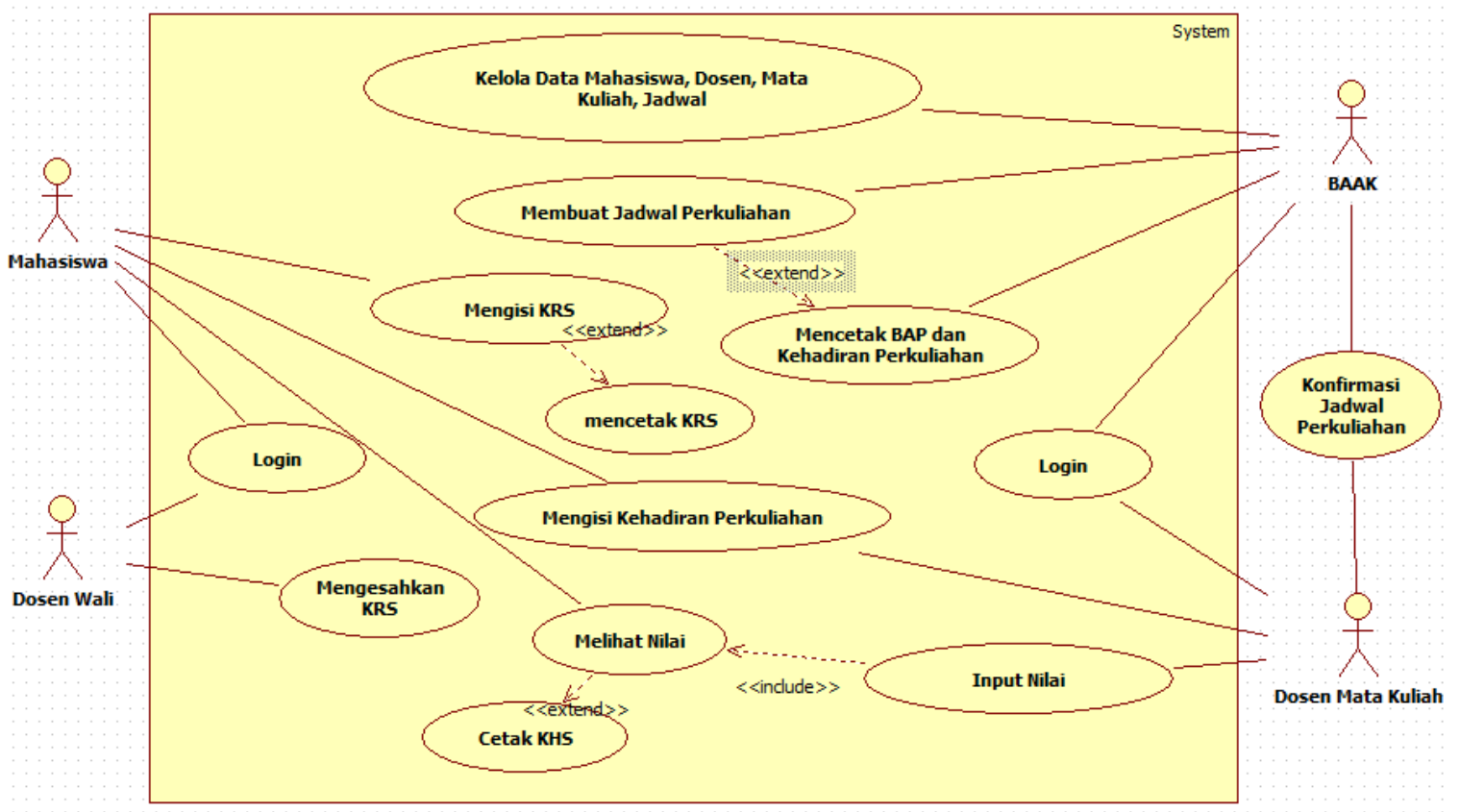

Gambar 4. Diagram Use Case Sistem Informasi Akademik yang diusulkan 
Adapun tabel deskripsi use case yang diusulkan adalah sebagai berikut :

Tabel 5. Tabel Deskripsi Use Case

\begin{tabular}{|c|c|c|c|}
\hline NO & NAMA USE CASE & AKTOR & DESKRIPSI \\
\hline 1 & $\begin{array}{l}\text { Kelola Data } \\
\text { Mahasiswa, Dosen, } \\
\text { Mata Kuliah, Jadwal }\end{array}$ & BAAK & $\begin{array}{l}\text { Menginput, mengedit, dan } \\
\text { menghapus data Mahasiswa, } \\
\text { Dosen, Mata Kuliah, dan } \\
\text { Jadwal }\end{array}$ \\
\hline 2 & $\begin{array}{l}\text { Membuat Jadwal } \\
\text { Perkuliahan }\end{array}$ & BAAK & $\begin{array}{l}\text { Membuat jadwal perkuliahan } \\
\text { dengan menentukan mata } \\
\text { kuliah dan dosen yang } \\
\text { jadwalkan pada suatu semester, } \\
\text { dan dapat mencetak Berita } \\
\text { Acara Perkuliahan (BAP) serta } \\
\text { mencetak lembar Kehadiran } \\
\text { perkuliahan jika diperlukan }\end{array}$ \\
\hline 3 & Mengisi KRS & Mahasiswa & $\begin{array}{l}\text { Menentukan mata kuliah yang } \\
\text { akan ditempuh pada suatu } \\
\text { semester, dan mahasiswa dapat } \\
\text { mencetak Kartu rencana Studi } \\
\text { (KRS) }\end{array}$ \\
\hline 4 & Mengesahkan KRS & Dosen Wali & $\begin{array}{l}\text { Mengecek kesesuaian dan } \\
\text { mengesahkan mata kuliah yang } \\
\text { diambil oleh mahasiswa }\end{array}$ \\
\hline 5 & $\begin{array}{l}\text { Mengisi Kehadiran } \\
\text { Perkuliahan }\end{array}$ & Dosen, Mahasiswa & $\begin{array}{l}\text { Mengisi kehadiran pada suatu } \\
\text { jadwal perkuliahan }\end{array}$ \\
\hline 6 & Input Nilai & Dosen Mata Kuliah & $\begin{array}{l}\text { Menginput nilai mahasiswa } \\
\text { sesuai mata kuliah yang } \\
\text { diambil }\end{array}$ \\
\hline 7 & Melihat Nilai & Mahasiswa & $\begin{array}{l}\text { Melihat Nilai yang telah } \\
\text { diinput oleh dosen dan bisa } \\
\text { mencetak menjadi Kartu Hasil } \\
\text { Studi }\end{array}$ \\
\hline 8 & Login & $\begin{array}{l}\text { BAAK, Mahasiswa, } \\
\text { Dosen Mata Kuliah, } \\
\text { Dosen Wali }\end{array}$ & $\begin{array}{l}\text { Sebagai proses verifikasi } \\
\text { bahwa user terdaftar pada } \\
\text { sistem dan untuk mengakses } \\
\text { sistem informasi akademik }\end{array}$ \\
\hline
\end{tabular}




\section{Diagram Class}

Class Diagram digunakan untuk menggambarkan kelas dan objek beserta relasinya pada sistem informasi akademik. Adapun class diagram pada sistem informasi akademik adalah sebagai berikut dapat dilihat pada gambar 5 .

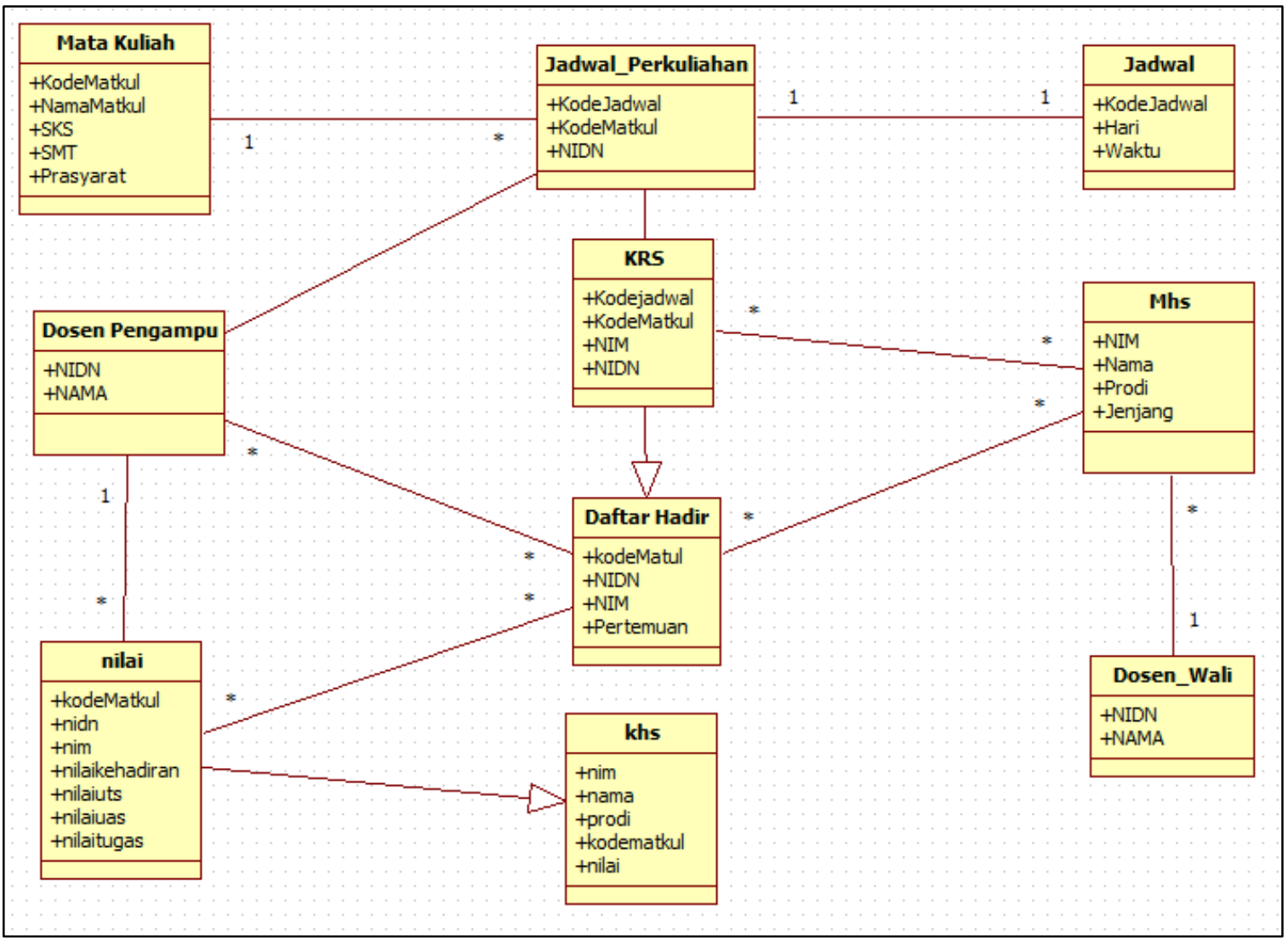

Gambar 5. Class Diagram Sistem Informasi Akademik

3. Diagram Sequence

a. Proses Login

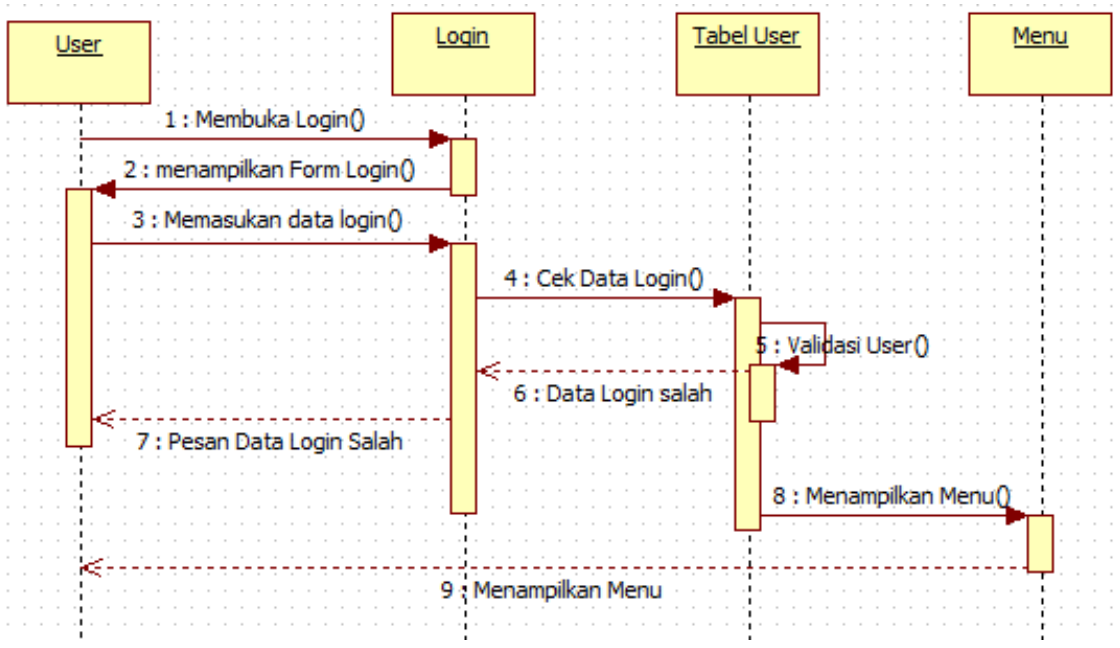

Gambar 6. Sequence Diagram Proses Login 


\section{b. Input Data Dosen}

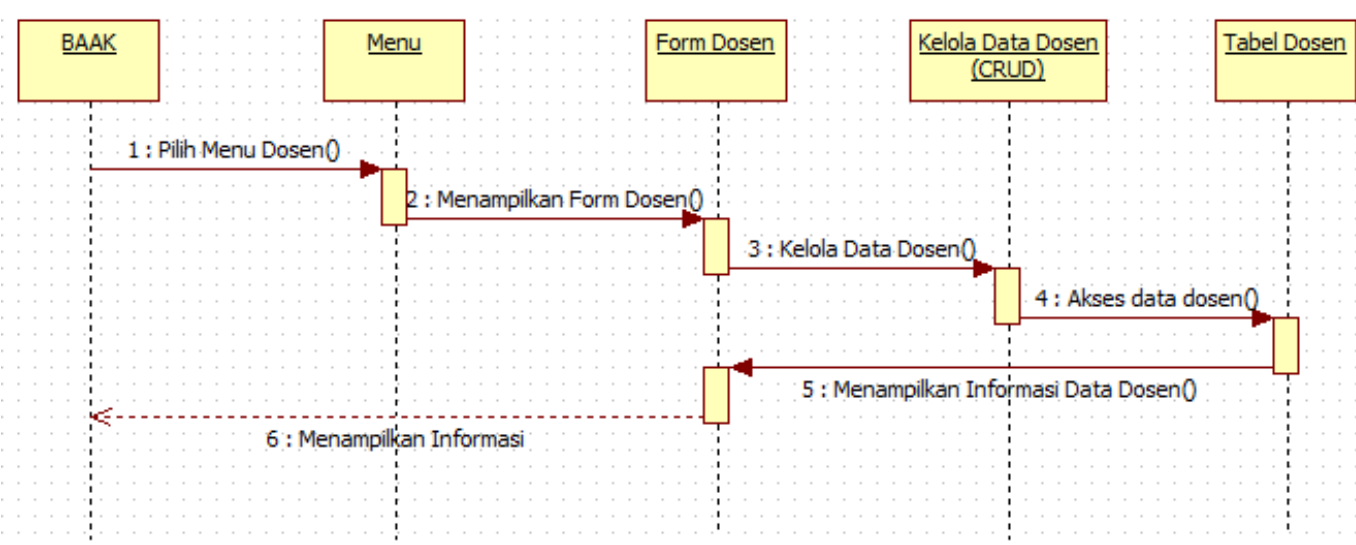

Gambar 7. Sequence Diagram Proses Input Data Dosen

c. Input Data Mahasiswa

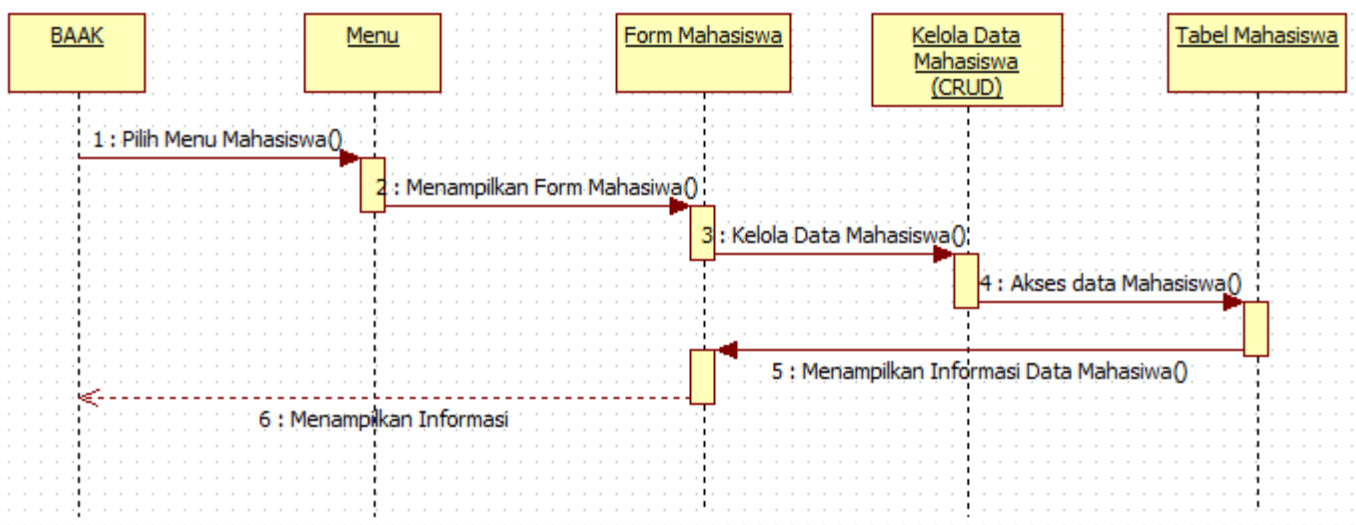

Gambar 8. Sequence Diagram Proses Input Data Mahasiswa

d. Input Mata Kuliah

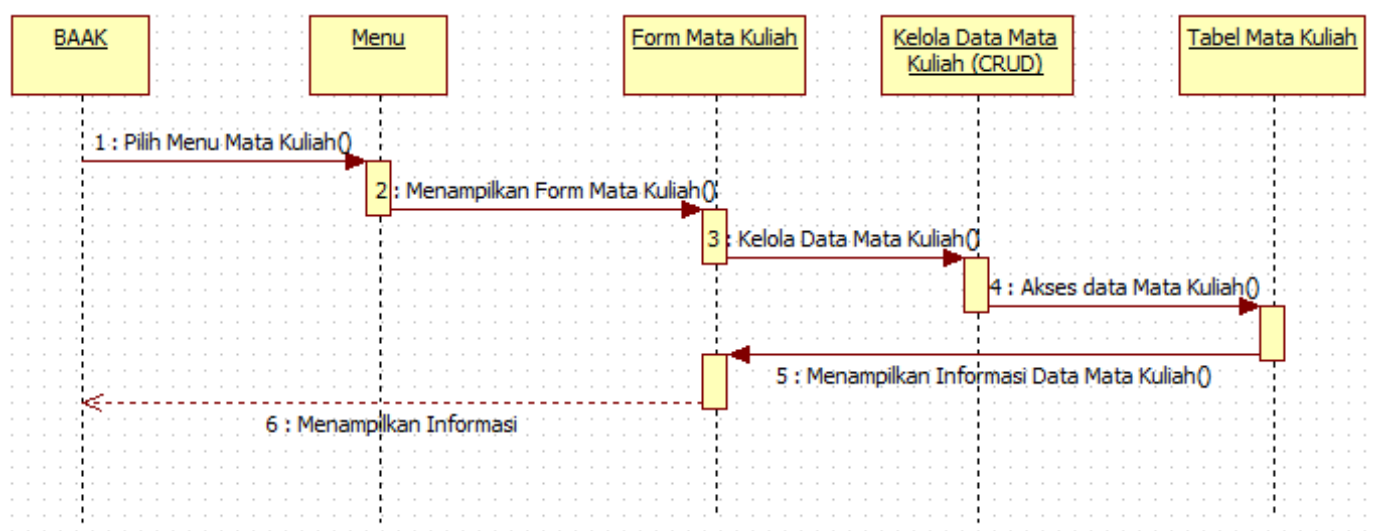

Gambar 9. Sequence Diagram Proses Input Mata Kuliah 
e. Input Data Jadwal

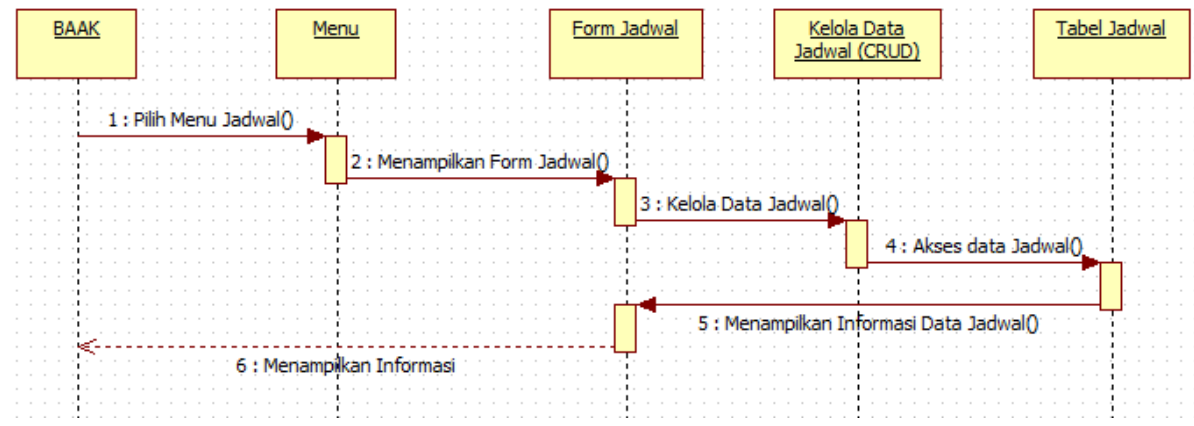

Gambar 10. Sequence Diagram Proses Input Data Jadwal

f. Membuat Pembuatan Jadwal Perkuliahan

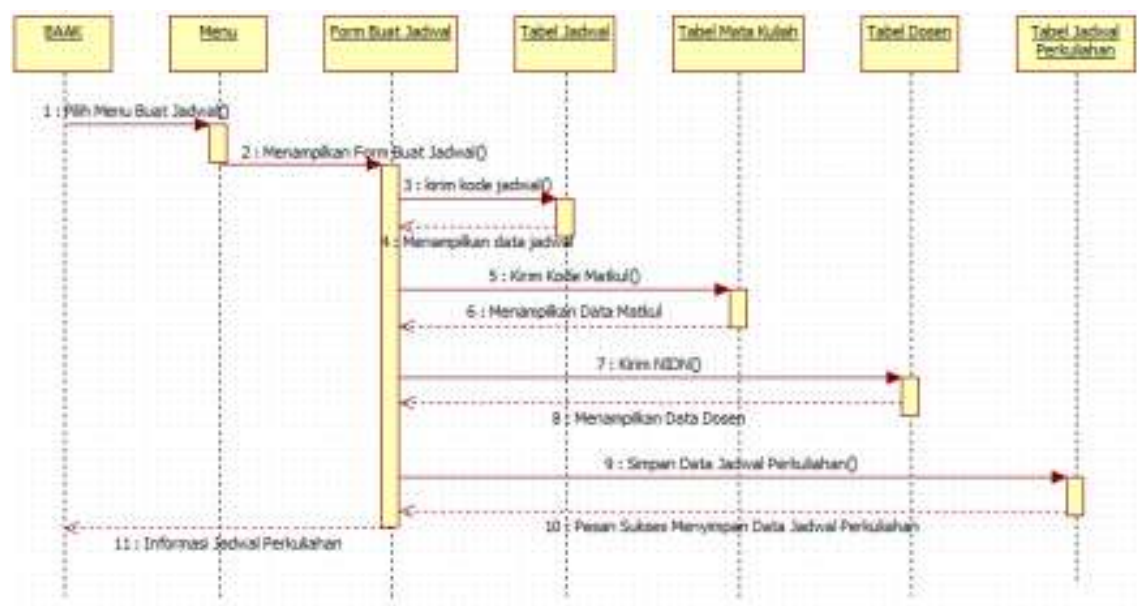

Gambar 11. Sequence Diagram Proses Pembuatan Jadwal Perkuliahan

g. Input KRS

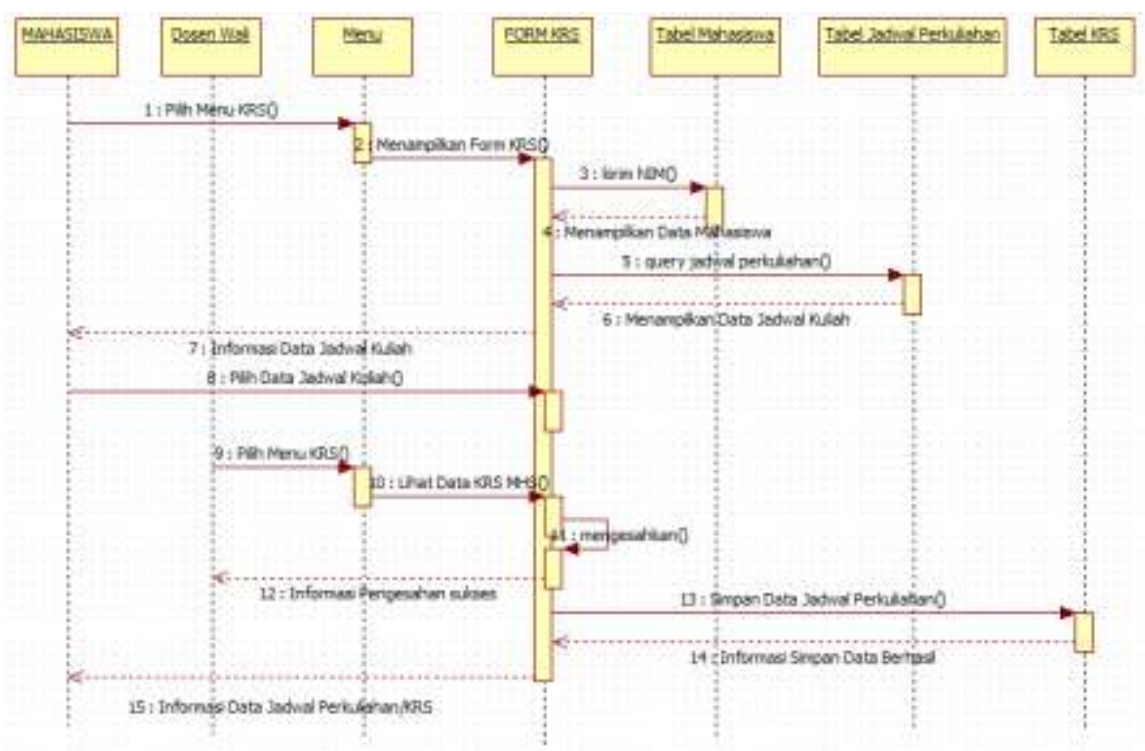

Gambar 12. Sequence Diagram Proses Input KRS 
h. Mengisi Kehadiran pada Perkuliahan

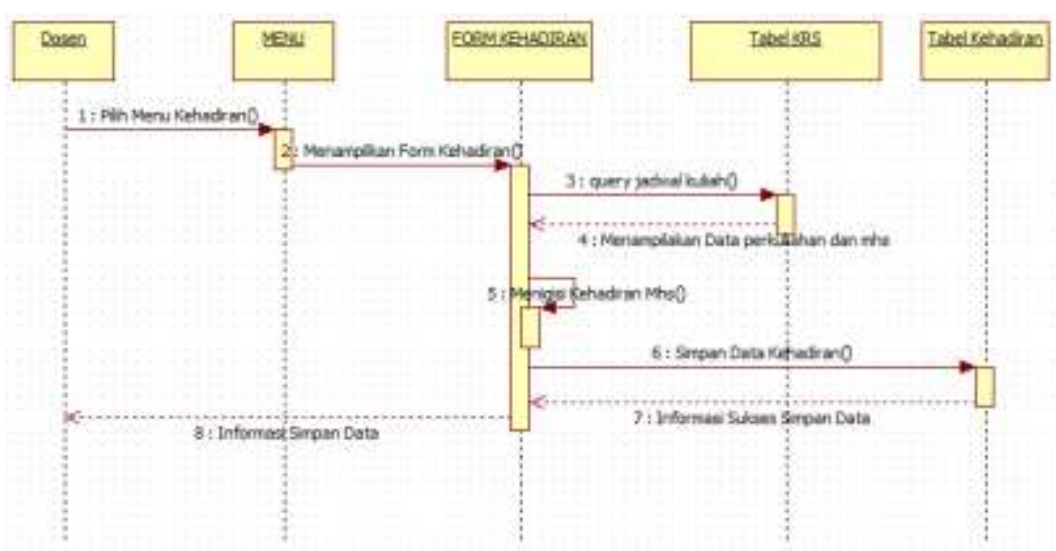

Gambar 13. Sequence Diagram Proses Mengisi Kehadiran pada Perkuliahan

i. Input Nilai

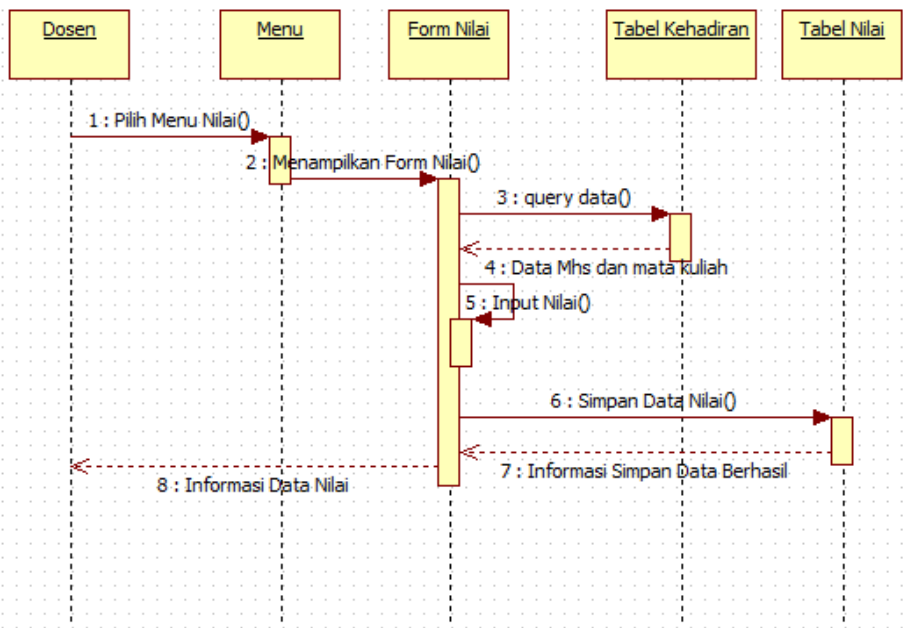

Gambar 14. Sequence Diagram Proses Input Nilai

j. Melihat Nilai dan mencetak KHS

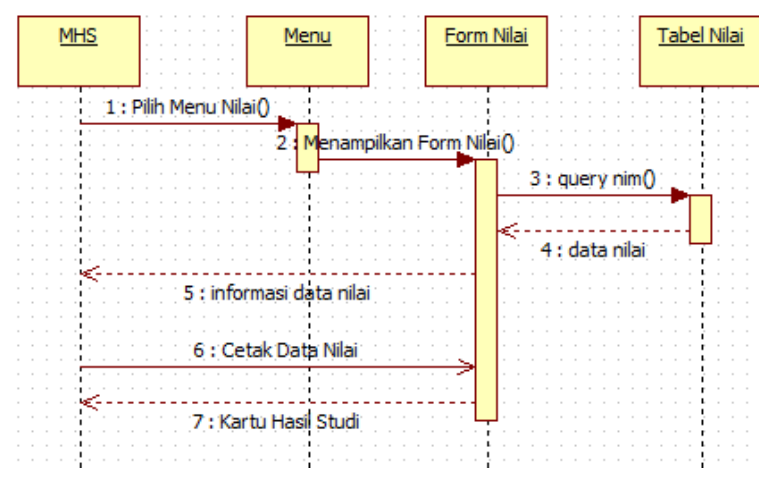

Gambar 15. Sequence Diagram Proses Melihat Nilai dan mencetak KHS

\section{Kesimpulan}


a. Sistem akademik yang berjalan pada Sekolah Tinggi Analis Bakti belum menggunakan sistem informasi sehingga pelayanan terhadap mahasiswa, dosen, dan pihak yang terkait relatf kurang efektif dan efisien. Karena data-data proses akademik disimpan pada file yang bersifat offline, sehingga pihak yang membutuhkan data tersebut tidak dapat mengakses langsung, contohnya nilai mahasiwa, dimana mahasisw jika ingin melihat nilai harus menunggu petugas BAAK untuk mencetak daftar nilai mahasiswa.

b. Dengan adanya sistem informasi akademik, pelayanan BAAK terhadap dosen dan mahasiswa dapat dilakukan secara efektif dan efisien. Dimana Dosen dapat mengisi langsung nilai mahasiswa secara online tanpa harus ke BAAK terlebih dahulu. Sehingga kesalahan input data nilai dapat dicegah, karena dosen lebih mengetahui perkembangan prestasi mahasiswa. Mahasiswa dapat melihat nilai secara online. Begitu juga orang tua mahasiswa dengan adanya sistem informasi akademik berbasis website, maka orang tua bisa melihat langsung nilai mahasiswa.

\section{DAFTAR PUSTAKA}

[1] Amarusu. (2009). Sistem informasi Akadmik sekolah.Medan: Andi

[2] Gelinas, Ulrich \& Dull, B. Richard, (2012). Accounting Information Systems, $9^{\text {th }}$ ed. South Western Cengage Learning. 5191 Natorp Boulevard Mason, USA. P. 19.

[3] Romney, Marshall B., dan Paul John Steinbart.2015.Accounting Information Systems, $13^{\text {th }}$ ed.England: Pearson Educational Limited.

[4] Mulyadi. 2016. Sistem Akuntansi: Jakarta: Salemba Empat

[5] Rosa. A.S.,dan Shalahuddin. M, Rekayasa Perangkat Lunak , $2^{\text {nd }}$ ed, Bandung:Informatika, 2014. 